\title{
Effects of LED photoperiods and light qualities on in vitro growth and chlorophyll fluorescence of Cunninghamia lanceolata
}

\author{
Yuanyuan $\mathrm{Xu}^{1,2}$, Mei Yang ${ }^{1 *} \mathbb{D}$, Fei Cheng ${ }^{1}$, Shinan Liu ${ }^{1}$ and Yuyao Liang ${ }^{3}$
}

\begin{abstract}
Background: Cunninghamia lanceolata (C. lanceolata) is the main fast-growing timber species in southern China. As an alternative to conventional lighting systems, LED has been demonstrated to be an artificial flexible lighting source for commercial micropropagation. The application of LED can provide rapid propagation of C. lanceolata in vitro culture.

Results: We applied two-factor randomized block design to study the effects of LED photoperiods and light qualities on the growth and chlorophyll fluorescence of $C$. lanceolata in vitro culture plantlets. In this study, plantlets were exposed to $20 \mathrm{\mu mol} \cdot \mathrm{m}^{-2} \cdot \mathrm{s}^{-1}$ irradiance for three photoperiods, 8,16 , and $24 \mathrm{~h}$ under the three composite lights, $88.9 \%$ red $+11.1 \%$ blue (R/B), $80.0 \%$ red $+10.0 \%$ blue $+10.0 \%$ purple (R/B/P), $72.7 \%$ red $+9.1 \%$ blue $+9.1 \%$ purple+ $9.1 \%$ green $(\mathrm{R} / \mathrm{B} / \mathrm{P} / \mathrm{G})$, as well as white light $(12.7 \% \mathrm{red}+3.9 \%$ blue $+83.4 \% \mathrm{green}, \mathrm{W})$ as control. The results showed that: (1) Plant height, dry weight, rooting rate, average root number, length, surface area and volume, chlorophyll, and chlorophyll fluorescence parameters were significantly affected by photoperiods, light qualities and their interactions. (2) Plantlets subjected to photoperiod $16 \mathrm{~h}$ had longer root, higher height, rooting rate, root number, and the higher levels of chlorophyll, chlorophyll a/b, Y (II), qP, NPQ/4 and ETR ${ }_{\|}$compared to photoperiods $8 \mathrm{~h}$ and $24 \mathrm{~h}$, while Fv/Fm during photoperiod $16 \mathrm{~h}$ was lower than $8 \mathrm{~h}$ and $24 \mathrm{~h}$. Plantlets exposed to $\mathrm{R} / \mathrm{B} / \mathrm{P} / \mathrm{G}$ generated more root and presented higher chlorophyll, Fv/Fo, $\mathrm{Y}(\mathrm{II})$, $\mathrm{PP}$, and ETR , than $\mathrm{W}$ during photoperiods 8 and $16 \mathrm{~h}$. (3) Total chlorophyll content and ETR were significant correlated with rooting rate, root length and root volume, while $\mathrm{Fv} / \mathrm{Fm}$ and $\mathrm{ETR}_{\|}$were significant correlated with plant height, average root number and root surface area. (4) $16-\mathrm{R} / \mathrm{B} / \mathrm{P} / \mathrm{G}$ is best for growing C. lanceolata plantlets in vitro.

Conclusions: This study demonstrated the effectiveness of photoperiods and light qualities using LEDs for micropropagation of C. lanceolata. The best plantlets were harvested under 16-R/B/P/G treatment. And there was a correlation between the growth and the chlorophyll and chlorophyll fluorescence of their leaves under different photoperiod and light quality. These results can contribute to improve the micropropagation process of this species.
\end{abstract}

Keywords: Light emitting diodes (LEDs), Photoperiod, Light quality, Cunninghamia lanceolata, Growth, Chlorophyll fluorescence

\footnotetext{
*Correspondence: fjyangmei@126.com

'Guangxi Key Laboratory of Forest Ecology and Conservation, College of

Forestry, Guangxi University, Nanning 530004, Guangxi, PR China

Full list of author information is available at the end of the article
}

(C) The Author(s). 2020 Open Access This article is licensed under a Creative Commons Attribution 4.0 International License, which permits use, sharing, adaptation, distribution and reproduction in any medium or format, as long as you give appropriate credit to the original author(s) and the source, provide a link to the Creative Commons licence, and indicate if changes were made. The images or other third party material in this article are included in the article's Creative Commons licence, unless indicated otherwise in a credit line to the material. If material is not included in the article's Creative Commons licence and your intended use is not permitted by statutory regulation or exceeds the permitted use, you will need to obtain permission directly from the copyright holder. To view a copy of this licence, visit http://creativecommons.org/licenses/by/4.0/. The Creative Commons Public Domain Dedication waiver (http://creativecommons.org/publicdomain/zero/1.0/) applies to the data made available in this article, unless otherwise stated in a credit line to the data. 


\section{Background}

As a signal and energy source, light is one the most important environment factors for plant growth and development in commercial micropropagation laboratories. Light quality (spectral quality), photoperiod and quantity (photon flux) have a profound influence on the morphogenesis and growth of plant cell, tissue and organ cultures [1]. As an alternative to conventional light sources for in vitro plant growth, light-emitting diodes (LEDs) have emerged with several unique advantages, including customizable spectra, small mass and volume, energy consumption, lower radiative heat emission, adjustable light intensity, longer lifetime, and high energyconversion efficiency $[2,3]$. Therefore, LED is applied to plant facility cultivation to solve the problems of luminous efficiency, high heat dissipation, high energy consumption, and mixed spectrum if using traditional light sources such as high-pressure sodium lamps, fluorescent lamps, metal halide lamps, and incandescent lamps [3].

The flexibility of matching wavelengths of LEDs to plant photoreceptors may provide more optimal production, influencing plant morphology and physiology $[2,4]$. The assessment of the effect of different LED wavelengths on the growth and development of in vitro plantlets of various plant species has drawn more attention [5]. However, the responses vary according to plant species and growth stages. Monochromatic red light can promote the germination of somatic embryos of Pinus densiflora [6]. Kwon et al. [7] pointed out that R/B (1:1) can promote cell division of Populus euramericana on in vitro culture than monochromatic light or fluorescence. Similarly, the biomass of stems and roots of Vaccinium corymbosum in vitro plantlets treated with R/ B (1:1) were significantly higher than monochromatic red and blue light [8]. Compared to white light (W), Eucalyptus, Musa, and Spathiphyllum showed higher growth of plantlets grown in vitro under a combination of red and blue light $(\mathrm{R} / \mathrm{B}, 4 / 1)$ [9]. Huang et al. [10] reported that R/B (5:5) could promote Apple Root-Stock JM7 germination in vitro, while R/B (6:4) was best to its proliferation and root growth. In the 'Favorita' potato (Solanum tuberosum L.) plantlets cultured in vitro, plant height was the greatest under monochromatic red light, whereas root length and fresh weight were the greatest under R/B (8/2), and chlorophyll content was the greatest under R/B (7/3) [11]. Cho et al. [12] pointed out that the combination of red and green light (R/G, 80/20) increased more than twice as much roots and dry mass compared with $\mathrm{W}$ in Coleus (Plectranthus scutellarioides) in vitro culture, and the exposure to the combination of red, green and blue light (R/G/B, 40/20/40) significantly increased the chlorophyll content. LED can influence the physiological process of plantlets cultured in vitro through the optimal combination of different light qualities, so as to promote the growth and improve the quality of plantlets.

Cunninghamia lanceolata (Lamb.) Hook. (Taxodiaceae, Cunninghamia) is one of the most popular timber tree species in architecture, furniture and other industries in China, because of its fast growth, soft material, straight texture and easy processing. It has been planted in China for more than 3000 years. At present, the planting area exceeds 11 million hectares, accounting for $20-30 \%$ of China's total commercial timber output [13, 14 . Clonal forestry has been playing an increasingly important role in plantation cultivation of commercial wood in some region. Clonal afforestation can not only keep the parent's excellent characteristics, but also establish a stable forest. In vitro regeneration plays a major role in the propagation of plant, producing a large number of plantlets with the identical characteristics as their parent plants. Recently, several in vitro regeneration protocols have been proposed for C. lanceolata, to improve biomass production of these rapidly growing, high quality trees, by selection of elite genotypes [15]. At present, the research on in vitro culture of C. lanceolata are mostly focused on the traditional methods, such as adjusting the basic medium and growth regulators, and its artificial light source is usually the traditional fluorescent lamp, which has the problem of slow growth of roots, resulting in low production efficiency and low economic benefit $[15,16]$. The application of LED in this field is still rare, only in the following two studies. Ding et al. [17] showed that the growth rate of C. lanceolata in vitro plantlets could be increased by using monochromatic red light in subculture stage, and then using monochromatic blue light could promote root and plantlet growth in rooting stage. Zhou et al. [18] pointed out that compared with monochromatic blue light and green light, $C$. lanceolata in vitro plantlets under monochromatic red light had the highest chlorophyll a, chlorophyll b, total chlorophyll content, photochemical efficiency of photosystem II (PSII) (Fv/Fo) and maximum quantum yield of PSII (Fv/Fm). However, there is no report on the study considering both photoperiod and light quality at the same time in vitro culture of $C$. lanceolata. On the other hand, chlorophyll fluorescence is a sensitive probe for plant photosynthesis, which has been widely used in recent years. It can be used to measure and study the dynamic changes of photosynthesis and to detect the effects of various external factors on plant growth [19]. What we are interested in is how the response of growth and chlorophyll fluorescence of $C$. lanceolata in vitro plantlets to LED photoperiod and light quality. What is the best photoperiod and light quality for in vitro culture of $C$. lanceolata? Under the LED, is there a certain relationship between the growth and chlorophyll fluorescence? Therefore, the objectives 
of this study were: 1) the examination of the effects of LED compound light, photoperiod and their interaction on the growth and chlorophyll fluorescence of C. lanceolata in vitro tissue culture; 2) the determination of the best combination of photoperiod and light quality for in vitro culture of C. lanceolata; 3 ) to study the relationship between the growth and chlorophyll fluorescence. We look forward the results of this study might provide data reference for discussing the effect of LED on the micropropagation process of $C$. lanceolata, and help to optimize technical approach for large-scale production in vitro culture of this commercial tree species.

\section{Results}

Effects of photoperiods and light qualities on the growth The growth of $C$. lanceolata in vitro plantlets was found to be significantly affected by the photoperiods, light qualities and their interactions. The height, dry weight, rooting rate, average root number, root length, root surface area, and volume were the highest at photoperiod $16 \mathrm{~h}$ at most light qualities (Table 1). And under this photoperiod, plantlets' roots and leaves were numerous, long, and evenly distributed (Fig. 1). With the photoperiods of 8 and $16 \mathrm{~h}$, height, rooting rate, root length, root surface area, and root volume were significantly higher in the $\mathrm{R} / \mathrm{B} / \mathrm{P} / \mathrm{G}$ compared to those with $\mathrm{R} / \mathrm{B}, \mathrm{R} / \mathrm{B} / \mathrm{P}$ and $\mathrm{W}(P<0.05)$. The dry weights were significantly enhanced in the $\mathrm{R} / \mathrm{B} / \mathrm{P}$ group for all three photoperiods compared to $\mathrm{W}$ treatment $(P<0.05)$. Rooting rate, root length, surface area, and volume reached the highest point with the $16-\mathrm{R} / \mathrm{B} / \mathrm{P} / \mathrm{G}$ treatment.

\section{Effects of photoperiods and light qualities on chlorophyll} Photoperiod and light quality significantly affected chlorophyll a, chlorophyll b, total chlorophyll content and chlorophyll $\mathrm{a} / \mathrm{b}$ of the leaves of $C$. lanceolata plantlets (Table 2). And there were significant interactions between photoperiods and light qualities. Plantlets exposed to the photoperiod $16 \mathrm{~h}$ exhibited the highest chlorophyll a, chlorophyll b, total chlorophyll content and chlorophyll a/b at most light qualities. During photoperiods 8 and $16 \mathrm{~h}$, chlorophyll a, chlorophyll b, total chlorophyll content and chlorophyll $\mathrm{a} / \mathrm{b}$ were significant higher in the $\mathrm{R} / \mathrm{B}$ and $\mathrm{R} / \mathrm{B} / \mathrm{P} / \mathrm{G}$ treatment compared to those in the $\mathrm{R} / \mathrm{B} / \mathrm{P}$ and $\mathrm{W}$ group $(P<0.05)$. The chlorophyll a, chlorophyll b, total chlorophyll content, and chlorophyll $\mathrm{a} / \mathrm{b}$ reached the highest point in the $\mathrm{R} / \mathrm{B}$ treatment during photoperiod $24 \mathrm{~h}$, respectively.

\section{Effects of photoperiods and light qualities on chlorophyll fluorescence}

Photoperiod and light quality significantly affected photochemical efficiency of photosystem II (PSII) (Fv/ Fo), maximum quantum yield of PSII (Fv/Fm), effective photochemical quantum yield of PSII (Y (II)), photochemical quenching coefficient $(\mathrm{qP})$, non-photochemical

Table 1 Effects of photoperiods and light qualities on the growth of C. lanceolata in vitro culture plantlets

\begin{tabular}{|c|c|c|c|c|c|c|c|c|}
\hline $\begin{array}{l}\text { Photoperiod/ } \\
h \cdot d^{-1} \text { (A) }\end{array}$ & $\begin{array}{l}\text { Light } \\
\text { quality }^{\mathrm{a}} \text { (B) }\end{array}$ & Height/cm & $\begin{array}{l}\text { Dry } \\
\text { weight /mg }\end{array}$ & $\begin{array}{l}\text { Rooting } \\
\text { rate/\% }\end{array}$ & $\begin{array}{l}\text { Average root } \\
\text { number }\end{array}$ & Root length/cm & $\begin{array}{l}\text { Root surface } \\
\text { area/ } / \mathrm{cm}^{2}\end{array}$ & Root volume $/ \mathrm{cm}^{3}$ \\
\hline \multirow[t]{4}{*}{8} & $R / B$ & $1.73 \pm 0.05^{b} i^{c}$ & $23.07 \pm 0.03 i$ & $32.50 \pm 1.50 \mathrm{~h}$ & $0.51 \pm 0.03 j$ & $1.10 \pm 0.02 k$ & $0.33 \pm 0.05 k$ & $0.34 \pm 0.02 \mathrm{i}$ \\
\hline & $\mathrm{R} / \mathrm{B} / \mathrm{P}$ & $1.65 \pm 0.03 j$ & $34.61 \pm 1.01 \mathrm{e}$ & $10.17 \pm 0.93 i$ & $0.20 \pm 0.02 k$ & $0.30 \pm 0.011$ & $0.08 \pm 0.011$ & $0.12 \pm 0.01 j$ \\
\hline & $\mathrm{R} / \mathrm{B} / \mathrm{P} / \mathrm{G}$ & $2.07 \pm 0.06 \mathrm{~g}$ & $29.21 \pm 1.02 \mathrm{~g}$ & $76.53 \pm 2.83 c$ & $2.06 \pm 0.02 \mathrm{~g}$ & $1.47 \pm 0.01 \mathrm{i}$ & $0.47 \pm 0.02 \mathrm{i}$ & $0.62 \pm 0.02 \mathrm{~g}$ \\
\hline & W & $1.98 \pm 0.03 \mathrm{~h}$ & $23.15 \pm 2.01 \mathrm{i}$ & $67.53 \pm 1.23 \mathrm{e}$ & $2.47 \pm 0.04 f$ & $1.27 \pm 0.22 \mathrm{j}$ & $0.46 \pm 0.01 j$ & $0.44 \pm 0.05 h$ \\
\hline \multirow[t]{4}{*}{16} & $\mathrm{R} / \mathrm{B}$ & $2.40 \pm 0.02 \mathrm{~d}$ & $37.22 \pm 3.01 c$ & $72.70 \pm 3.03 d$ & $2.85 \pm 0.03 \mathrm{e}$ & $2.52 \pm 0.20 \mathrm{c}$ & $0.66 \pm 0.01 \mathrm{e}$ & $0.78 \pm 0.05 d$ \\
\hline & $\mathrm{R} / \mathrm{B} / \mathrm{P}$ & $2.44 \pm 0.03 d$ & $46.13 \pm 3.42 \mathrm{a}$ & $65.83 \pm 4.50 f$ & $3.61 \pm 0.03 d$ & $3.85 \pm 0.11 \mathrm{~d}$ & $1.18 \pm 0.05 c$ & $0.80 \pm 0.04 c$ \\
\hline & $\mathrm{R} / \mathrm{B} / \mathrm{P} / \mathrm{G}$ & $2.63 \pm 0.02 b$ & $32.77 \pm 2.12 f$ & $95.50 \pm 3.04 \mathrm{a}$ & $4.45 \pm 0.04 b$ & $5.95 \pm 0.30 \mathrm{a}$ & $1.92 \pm 0.07 a$ & $1.02 \pm 0.02 \mathrm{a}$ \\
\hline & W & $2.41 \pm 0.02 d$ & $20.53 \pm 0.93 j$ & $86.60 \pm 3.51 b$ & $4.63 \pm 0.05 a$ & $4.71 \pm 0.50 b$ & $1.49 \pm 0.03 b$ & $1.02 \pm 0.05 \mathrm{a}$ \\
\hline \multirow[t]{4}{*}{24} & $\mathrm{R} / \mathrm{B}$ & $2.71 \pm 0.01 \mathrm{a}$ & $35.47 \pm 3.02 \mathrm{~d}$ & $85.37 \pm 3.78 b$ & $1.85 \pm 0.10 \mathrm{~h}$ & $2.42 \pm 0.27 \mathrm{e}$ & $0.72 \pm 0.01 d$ & $0.93 \pm 0.03 b$ \\
\hline & $\mathrm{R} / \mathrm{B} / \mathrm{P}$ & $2.52 \pm 0.02 c$ & $43.27 \pm 3.52 b$ & $67.40 \pm 2.00 \mathrm{e}$ & $2.43 \pm 0.02 f$ & $2.04 \pm 0.21 \mathrm{f}$ & $0.55 \pm 0.02 \mathrm{~g}$ & $0.72 \pm 0.02 \mathrm{e}$ \\
\hline & $\mathrm{R} / \mathrm{B} / \mathrm{P} / \mathrm{G}$ & $2.12 \pm 0.02 f$ & $36.90 \pm 3.46 c$ & $75.60 \pm 2.02 c$ & $3.92 \pm 0.03 c$ & $1.85 \pm 0.26 \mathrm{~g}$ & $0.63 \pm 0.05 f$ & $0.72 \pm 0.04 \mathrm{e}$ \\
\hline & W & $2.21 \pm 0.02 \mathrm{e}$ & $27.17 \pm 2.31 \mathrm{~h}$ & $61.40 \pm 1.87 \mathrm{~g}$ & $1.46 \pm 0.03 i$ & $1.56 \pm 0.43 \mathrm{~h}$ & $0.50 \pm 0.02 \mathrm{~h}$ & $0.66 \pm 0.05 f$ \\
\hline \multirow[t]{3}{*}{ F-test } & $A$ & $* *$ & $* *$ & $* *$ & $* *$ & $* *$ & $* *$ & $* *$ \\
\hline & B & $* *$ & $* *$ & $* *$ & $* *$ & $* *$ & $* *$ & $* *$ \\
\hline & $A \times B$ & $* *$ & $* *$ & $* *$ & $* *$ & $* *$ & $* *$ & $* *$ \\
\hline
\end{tabular}

\footnotetext{
${ }^{a}$ The light qualities are R/B (88.9\% red $+11.1 \%$ blue), R/B/P (80.0\% red $+10.0 \%$ blue $+10.0 \%$ purple), R/B/P/G $(72.7 \%$ red $+9.1 \%$ blue $+9.1 \%$ purple $+9.1 \%$ green), $W$ $(12.7 \%$ red $+3.9 \%$ blue $+83.4 \%$ green $)$

${ }^{\mathrm{b}}$ mean \pm standard deviation, $n=3$

c Any two means within a column not followed by the same letter are significantly different at $P<0.05$ by ANOVA on Duncan's multiple range test

${ }^{* *}$ mean significant at $P<0.01$
} 


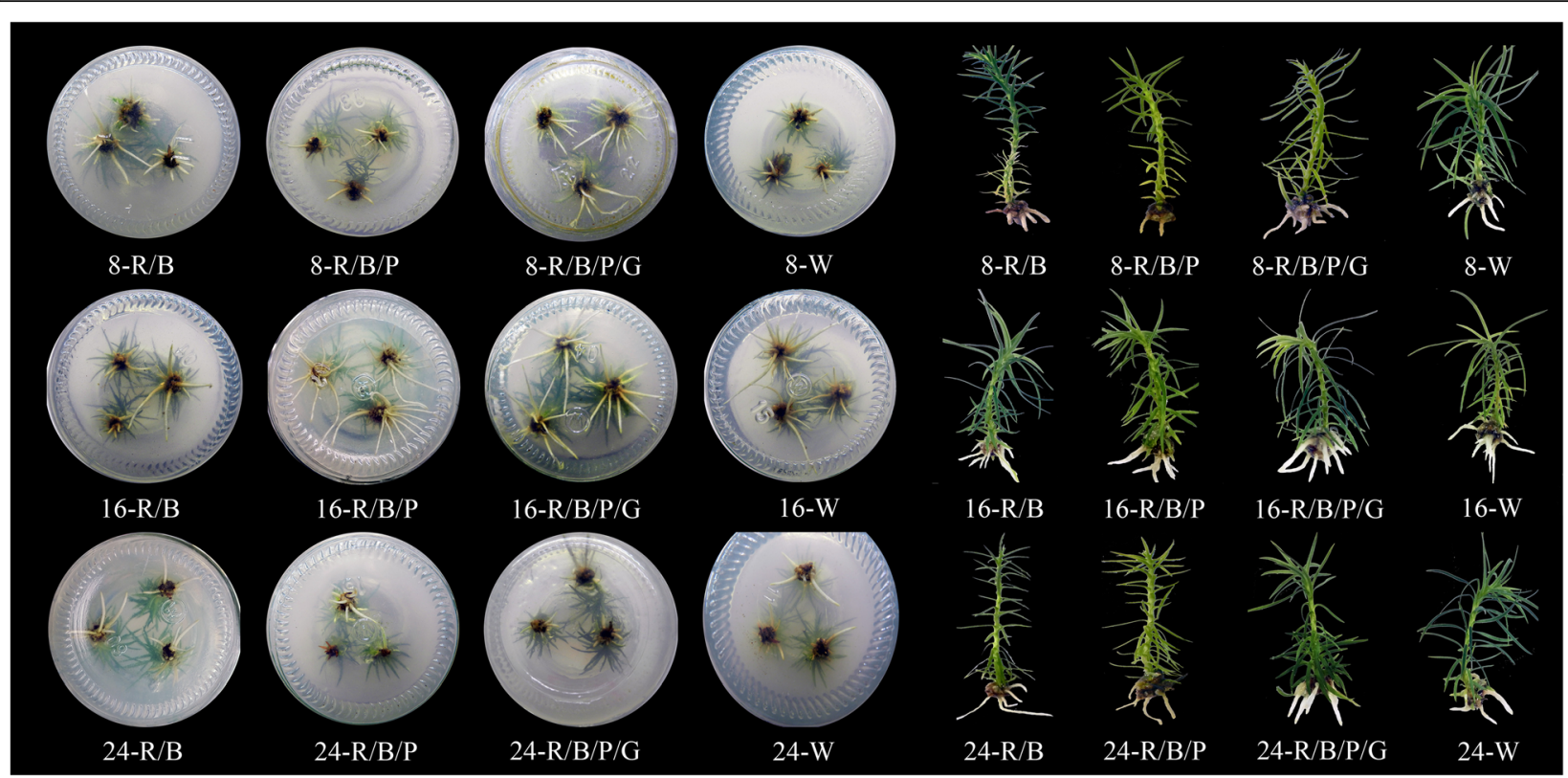

Fig. 1 Growth of C. lanceolata in vitro culture plantlets under different photoperiods and light qualities. 8, 16 and 24 refer to photoperiod 8, 16, $24 \mathrm{~h}$, respectively; R/B, R/B/P, R/B/P/G, and W refer to light quality R/B (88.9\% red $+11.1 \%$ blue), R/B/P ( $80.0 \%$ red $+10.0 \%$ blue+ $10.0 \%$ purple), R/B/ P/G (72.7\% red+9.1\% blue+ $9.1 \%$ purple+ $9.1 \%$ green $)$, W $(12.7 \%$ red $+3.9 \%$ blue $+83.4 \%$ green $)$

Table 2 Effects of photoperiods and light qualities on chlorophyll content of C. lanceolata in vitro culture plantlets

\begin{tabular}{|c|c|c|c|c|c|}
\hline $\begin{array}{l}\text { Photoperiod/ h.d } \mathrm{d}^{-1} \\
\text { (A) }\end{array}$ & $\begin{array}{l}\text { Light quality } \\
\text { (B) }\end{array}$ & $\begin{array}{l}\text { Chlorophyll a content/ } \\
\mathrm{mg} \cdot \mathrm{g}^{-1} \mathrm{FW}\end{array}$ & $\begin{array}{l}\text { Chlorophyll b content/ } \\
\mathrm{mg} \cdot \mathrm{g}^{-1} \mathrm{FW}\end{array}$ & $\begin{array}{l}\text { Total chlorophyll content/ } \\
\mathrm{mg} \cdot \mathrm{g}^{-1} \mathrm{FW}\end{array}$ & $\begin{array}{l}\text { Chlorophyll } \\
\text { a/b }\end{array}$ \\
\hline \multirow[t]{4}{*}{8} & $R / B$ & $1.02 \pm 0.07^{b} d^{c}$ & $0.63 \pm 0.04 d$ & $1.65 \pm 0.12 \mathrm{~d}$ & $1.64 \pm 0.01 \mathrm{~d}$ \\
\hline & $\mathrm{R} / \mathrm{B} / \mathrm{P}$ & $0.56 \pm 0.03 f$ & $0.40 \pm 0.01 \mathrm{f}$ & $0.96 \pm 0.04 \mathrm{~g}$ & $1.41 \pm 0.03 \mathrm{e}$ \\
\hline & $\mathrm{R} / \mathrm{B} / \mathrm{P} / \mathrm{G}$ & $1.43 \pm 0.10 \mathrm{a}$ & $0.79 \pm 0.04 \mathrm{a}$ & $2.22 \pm 0.14 \mathrm{a}$ & $\begin{array}{l}1.81 \pm 0.04 \\
a b\end{array}$ \\
\hline & W & $0.64 \pm 0.02 f$ & $0.47 \pm 0.01 \mathrm{e}$ & $1.11 \pm 0.03 f$ & $1.37 \pm 0.01 \mathrm{e}$ \\
\hline \multirow[t]{4}{*}{16} & $\mathrm{R} / \mathrm{B}$ & $1.30 \pm 0.01 b$ & $0.69 \pm 0.05 b c$ & $1.99 \pm 0.04 b$ & $1.87 \pm 0.13 a$ \\
\hline & $\mathrm{R} / \mathrm{B} / \mathrm{P}$ & $1.17 \pm 0.06 c$ & $0.66 \pm 0.03 \mathrm{~cd}$ & $1.83 \pm 0.08 c$ & $\begin{array}{l}1.77 \pm 0.03 \\
b c\end{array}$ \\
\hline & $\mathrm{R} / \mathrm{B} / \mathrm{P} / \mathrm{G}$ & $1.35 \pm 0.07 a b$ & $0.72 \pm 0.02 \mathrm{~cd}$ & $2.08 \pm 0.09 b$ & $\begin{array}{l}1.86 \pm 0.07 \\
a b\end{array}$ \\
\hline & W & $1.13 \pm 0.04 c$ & $0.64 \pm 0.01 d$ & $1.77 \pm 0.05 \mathrm{~cd}$ & $\begin{array}{l}1.77 \pm 0.02 \\
\text { bc }\end{array}$ \\
\hline \multirow[t]{4}{*}{24} & $\mathrm{R} / \mathrm{B}$ & $0.84 \pm 0.07$ e & $0.50 \pm 0.03 \mathrm{e}$ & $1.33 \pm 0.10 \mathrm{e}$ & $1.69 \pm 0.04 c d$ \\
\hline & $R / B / P$ & $0.32 \pm 0.01 \mathrm{~g}$ & $0.22 \pm 0.01 \mathrm{~h}$ & $0.54 \pm 0.01 \mathrm{~h}$ & $1.43 \pm 0.09 \mathrm{e}$ \\
\hline & $\mathrm{R} / \mathrm{B} / \mathrm{P} / \mathrm{G}$ & $0.29 \pm 0.02 \mathrm{~g}$ & $0.26 \pm 0.01 \mathrm{~g}$ & $0.55 \pm 0.03 \mathrm{~h}$ & $1.14 \pm 0.03 f$ \\
\hline & W & $0.34 \pm 0.02 \mathrm{~g}$ & $0.28 \pm 0.01 \mathrm{~g}$ & $0.62 \pm 0.03 \mathrm{~h}$ & $1.20 \pm 0.04 f$ \\
\hline \multirow[t]{3}{*}{ F-test } & A & $* *$ & $* *$ & $* *$ & ** \\
\hline & B & $* *$ & $* *$ & $* *$ & $* *$ \\
\hline & $A \times B$ & $* *$ & $* *$ & $* *$ & $* *$ \\
\hline
\end{tabular}

\footnotetext{
${ }^{a}$ The light qualities are R/B (88.9\% red+ $11.1 \%$ blue), R/B/P (80.0\% red $+10.0 \%$ blue $+10.0 \%$ purple), R/B/P/G $(72.7 \%$ red $+9.1 \%$ blue $+9.1 \%$ purple $+9.1 \%$ green), $W$ (12.7\% red $+3.9 \%$ blue $+83.4 \%$ green)

${ }^{\mathrm{b}}$ mean \pm standard deviation, $\mathrm{n}=3$

c Any two means within a column not followed by the same letter are significantly different at $P<0.05$ by ANOVA on Duncan's multiple range test

***an significant at $P<0.01$
} 
quenching coefficient (NPQ/4), and relative electron transport rate in PSII $\left(\mathrm{ETR}_{\mathrm{II}}\right)$ of the leaves of C. lanceolata plantlets (Table 3). And there were significant interactions between photoperiods and light qualities. Plantlets exposed to the photoperiod $16 \mathrm{~h}$ exhibited the

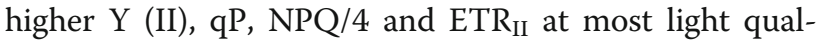
ities compared to those with photoperiods $8 \mathrm{~h}$ and $24 \mathrm{~h}$, but $\mathrm{Fv} / \mathrm{Fm}$ during photoperiod $16 \mathrm{~h}$ was lower than $8 \mathrm{~h}$ and $24 \mathrm{~h}$. And the $\mathrm{Fv} / \mathrm{Fm}$ value of different treatments was between 0.784-0.854. During photoperiods 8 and $16 \mathrm{~h}$, the $\mathrm{Fv} / \mathrm{Fo}, \mathrm{Y}(\mathrm{II}), \mathrm{qP}$, and $\mathrm{ETR}_{\mathrm{II}}$ were significantly greater under the $\mathrm{R} / \mathrm{B} / \mathrm{P} / \mathrm{G}$ treatment than $\mathrm{R} / \mathrm{B}, \mathrm{R} / \mathrm{B} / \mathrm{P}$ and $\mathrm{W}(P<0.05)$. On the other hand, there was no significant difference in $\mathrm{Fv} / \mathrm{Fm}$ between $\mathrm{R} / \mathrm{B}, \mathrm{R} / \mathrm{B} / \mathrm{P}, \mathrm{B} / \mathrm{R} / \mathrm{P} /$ $\mathrm{G}$ and $\mathrm{W}$ under photoperiod $16 \mathrm{~h}$.

\section{Relationship between growth and chlorophyll fluorescence parameters}

Among environmental conditions, light is a predominant source of energy for plant photosynthesis and also an important signal for plant growth and development [20]. Studying the relationship between plant growth and chlorophyll fluorescence under LED can preliminarily reveal the response mechanism of plantlets to light environment. So, we used the growth parameters (plant height, dry weight, rooting rate, average root, root length, root surface area and root volume) as the dependent variable, and the chlorophyll a, chlorophyll b, total chlorophyll content, chlorophyll $\mathrm{a} / \mathrm{b}$ and chlorophyll fluorescence parameters (Fv/Fo, Fv/Fm, Y(II), qP, $\mathrm{NPQ} / 4, \mathrm{ETR}_{\mathrm{II}}$ ) as independent variables for multivariate stepwise regression analysis. The results (Table 4) showed that $\mathrm{Fv} / \mathrm{Fm}, \mathrm{Y}(\mathrm{II})$, and $\mathrm{ETR}_{\mathrm{II}}$ were significant correlated with plant height $(P<0.001)$, while the chlorophyll and chlorophyll fluorescence parameters was not correlated with dry weight. ETR $\mathrm{EII}_{\mathrm{II}}$ and total chlorophyll content were significant correlated with rooting rate $(P<0.001) ; \mathrm{FV} / \mathrm{Fo}$ and $\mathrm{ETR}_{\mathrm{II}}(P<0.001)$ were significant correlated with average root number; $\mathrm{Fv} / \mathrm{Fm}, \mathrm{ETR}_{\mathrm{II}}$, and total chlorophyll content were significant correlated

Table 3 Effects of photoperiods and light qualities on chlorophyll fluorescence of C. lanceolata in vitro culture plantlets

\begin{tabular}{|c|c|c|c|c|c|c|c|}
\hline $\begin{array}{l}\text { Photoperiod/h.d } \mathrm{d}^{-1} \\
\text { (A) }\end{array}$ & $\begin{array}{l}\text { Light quality }{ }^{a} \\
\text { (B) }\end{array}$ & $\mathrm{Fv} / \mathrm{Fo}$ & $\mathrm{Fv} / \mathrm{Fm}$ & $Y(I I)$ & $q^{P}$ & $\mathrm{NPQ} / 4$ & $\mathrm{ETR}_{\|}$ \\
\hline \multirow[t]{4}{*}{8} & $\mathrm{R} / \mathrm{B}$ & $\begin{array}{l}1.374 \pm 0.105^{b} \\
d e^{c}\end{array}$ & $0.814 \pm 0.009 \mathrm{~cd}$ & $0.034 \pm 0.003 e$ & $\begin{array}{l}0.078 \pm 0.004 \\
\text { cde }\end{array}$ & $0.192 \pm 0.026 b$ & $2.428 \pm 0.220 \mathrm{e}$ \\
\hline & $\mathrm{R} / \mathrm{B} / \mathrm{P}$ & $1.348 \pm 0.049 \mathrm{de}$ & $\begin{array}{l}0.812 \pm 0.005 \\
\text { cde }\end{array}$ & $0.036 \pm 0.002 \mathrm{e}$ & $0.038 \pm 0.003 f$ & $0.234 \pm 0.007 a$ & $1.697 \pm 0.057 \mathrm{e}$ \\
\hline & $\mathrm{R} / \mathrm{B} / \mathrm{P} / \mathrm{G}$ & $1.754 \pm 0.037 \mathrm{ab}$ & $0.854 \pm 0.002 \mathrm{a}$ & $\begin{array}{l}0.050 \pm 0.005 \\
\mathrm{~cd}\end{array}$ & $0.095 \pm 0.007 b c$ & $0.171 \pm 0.007 \mathrm{ab}$ & $\begin{array}{l}5.074 \pm 0.638 \\
\text { bc }\end{array}$ \\
\hline & W & $1.402 \pm 0.079 \mathrm{de}$ & $\begin{array}{l}0.803 \pm 0.005 \\
\text { def }\end{array}$ & $0.050 \pm 0.00 \mathrm{~cd}$ & $0.072 \pm 0.006 \mathrm{de}$ & $0.164 \pm 0.017 \mathrm{de}$ & $3.533 \pm 0.153 d$ \\
\hline \multirow[t]{4}{*}{16} & $R / B$ & $1.283 \pm 0.070 \mathrm{e}$ & $0.792 \pm 0.013$ ef & $0.035 \pm 0.004 \mathrm{e}$ & $0.062 \pm 0.001 \mathrm{e}$ & $0.217 \pm 0.010 a$ & $3.241 \pm 0.236 d$ \\
\hline & $\mathrm{R} / \mathrm{B} / \mathrm{P}$ & $1.300 \pm 0.092 \mathrm{de}$ & $0.788 \pm 0.010 f$ & $0.035 \pm 0.002 \mathrm{e}$ & $0.064 \pm 0.010 \mathrm{e}$ & $\begin{array}{l}0.168 \pm 0.011 \\
\text { cde }\end{array}$ & $3.413 \pm 0.250 d$ \\
\hline & $R / B / P / G$ & $1.422 \pm 0.051 \mathrm{de}$ & $0.784 \pm 0.018 f$ & $\begin{array}{l}0.064 \pm 0.003 \\
a b\end{array}$ & $0.138 \pm 0.014 a$ & $0.151 \pm 0.013 \mathrm{e}$ & $6.585 \pm 0.265 a$ \\
\hline & W & $1.287 \pm 0.028 \mathrm{e}$ & $\begin{array}{l}0.802 \pm 0.014 \\
\text { def }\end{array}$ & $\begin{array}{l}0.059 \pm 0.006 \\
b c\end{array}$ & $0.102 \pm 0.003 b$ & $0.220 \pm 0.008 a$ & $5.711 \pm 0.575 b$ \\
\hline \multirow[t]{4}{*}{24} & $\mathrm{R} / \mathrm{B}$ & $1.439 \pm 0.050 \mathrm{~d}$ & $0.792 \pm 0.016$ ef & $\begin{array}{l}0.040 \pm 0.005 \\
\text { de }\end{array}$ & $0.077 \pm 0.004 \mathrm{de}$ & $0.150 \pm 0.010 \mathrm{e}$ & $4.817 \pm 0.324 c$ \\
\hline & $\mathrm{R} / \mathrm{B} / \mathrm{P}$ & $1.573 \pm 0.015 c$ & $0.826 \pm 0.014 b c$ & $\begin{array}{l}0.043 \pm 0.004 \\
\text { de }\end{array}$ & $0.031 \pm 0.023 f$ & $0.189 \pm 0.021 b c$ & $4.344 \pm 0.820 c$ \\
\hline & $\mathrm{R} / \mathrm{B} / \mathrm{P} / \mathrm{G}$ & $1.691 \pm 0.072 b c$ & $0.843 \pm 0.002 \mathrm{ab}$ & $0.071 \pm 0.007 a$ & $\begin{array}{l}0.086 \pm 0.009 \\
\text { bcd }\end{array}$ & $0.161 \pm 0.019 \mathrm{de}$ & $7.311 \pm 0.019 a$ \\
\hline & W & $1.854 \pm 0.162 \mathrm{a}$ & $0.843 \pm 0.014 \mathrm{ab}$ & $0.048 \pm 0.004 d$ & $0.097 \pm 0.008 b$ & $\begin{array}{l}0.179 \pm 0.017 \\
\text { bcd }\end{array}$ & $\begin{array}{l}4.933 \pm 0.379 \\
b c\end{array}$ \\
\hline \multirow[t]{3}{*}{ F-test } & A & $* *$ & $* *$ & $* *$ & $* *$ & $* *$ & $* *$ \\
\hline & B & $* *$ & $* *$ & $* *$ & $* *$ & $* *$ & $* *$ \\
\hline & $A \times B$ & $* *$ & $* *$ & * & $* *$ & $* *$ & $* *$ \\
\hline
\end{tabular}

\footnotetext{
${ }^{a}$ The light qualities are R/B (88.9\% red $+11.1 \%$ blue), R/B/P ( $80.0 \%$ red $+10.0 \%$ blue $+10.0 \%$ purple), R/B/P/G $(72.7 \%$ red $+9.1 \%$ blue $+9.1 \%$ purple+ $9.1 \%$ green), $\mathrm{W}$ $(12.7 \%$ red $+3.9 \%$ blue $+83.4 \%$ green)

b mean \pm standard deviation, $n=3$

c Any two means within a column not followed by the same letter are significantly different at $P<0.05$ by ANOVA on Duncan's multiple range test

${ }^{*},{ }^{* *}$ mean significant at $0.01<P<0.05$ and $P<0.01$, respectively
} 
Table 4 Linear regression model of plant growth parameters and chlorophyll, chlorophyll fluorescence parameters

\begin{tabular}{|c|c|c|c|c|}
\hline Growth parameters & Linear regression model & AlC & $R^{2}$ & P \\
\hline Plant height & $y=8.028-7.074 x_{1}-34.508 x_{2}+0.359 x_{3}$ & -30.584 & 0.882 & 0.000 \\
\hline Rooting rate & $y=-46.617+11.847 x_{3}+38.395 x_{4}$ & 77.915 & 0.796 & 0.001 \\
\hline Average root & $y=5.379+0.867 \times x_{3}-4.520 \times_{5}$ & 9.754 & 0.809 & 0.001 \\
\hline Root length & $y=25.812-36.655 x_{1}+0.687 x_{3}+2.123 \times_{4}$ & 7.718 & 0.856 & 0.001 \\
\hline Root surface area & $y=12.271-15.441 x_{1}+0.232 x_{3}$ & -13.118 & 0.787 & 0.001 \\
\hline Root volume & $y=-1.574+0.129 \times_{3}+1.418 \times_{4}-0.401 x_{6}$ & -33.983 & 0.861 & 0.001 \\
\hline
\end{tabular}

AIC Akaike information criterion, $R^{2} \mathrm{R}$ Square, $x_{1} \mathrm{Fv} / \mathrm{Fm}, x_{2} \mathrm{Y}(\mathrm{II}), x_{3} \mathrm{ETR}_{\mathrm{Il}}, x_{4}$ Total chlorophyll content, $x_{5} \mathrm{Fv} / \mathrm{Fo}, x_{6}$ Chlorophyll a/b.

with root length $(P<0.001) ; \mathrm{Fv} / \mathrm{Fm}$ and $\mathrm{ETR}_{\mathrm{II}}$ were significant correlated with root surface area $(P<0.001)$; ETR $\mathrm{II}$, total chlorophyll content, and chlorophyll $\mathrm{a} / \mathrm{b}$ ratio were significant correlated with root volume $(P<0.001)$.

\section{Principal component analysis}

The principal component analysis of 17 parameters of the $C$. lanceolata in vitro culture plantlets under different LED treatments was conducted. The results showed that the eigenvalues of the first four principal components, PC1, PC2, PC3, and PC4 were all greater than 1, and the cumulative contribution rate reached $89.927 \%$, indicating that these four principal factors could be used to explain $89.927 \%$ of the variation in our data (Table 5, Fig. 2a). The first principal component PC1 could

Table 5 Rotated component matrix of PCA

\begin{tabular}{lllll}
\hline Factor & \multicolumn{4}{l}{ Principal components } \\
\cline { 2 - 5 } & PC1 & PC2 & PC3 & PC4 \\
\hline Plant height & 0.743 & 0.205 & -0.516 & 0.213 \\
Dry weight & 0.020 & 0.024 & -0.780 & 0.423 \\
Rooting rate & 0.849 & 0.383 & -0.051 & 0.161 \\
Average root & 0.829 & 0.293 & -0.158 & -0.248 \\
Root length & 0.939 & 0.002 & -0.159 & -0.198 \\
Root surface area & 0.931 & 0.044 & -0.096 & -0.237 \\
Root volume & 0.885 & 0.262 & -0.242 & 0.067 \\
Chlorophyll a & 0.653 & -0.643 & 0.318 & 0.210 \\
Chlorophyll b & 0.598 & -0.663 & 0.394 & 0.181 \\
Total chlorophyll & 0.665 & -0.688 & 0.049 & 0.209 \\
Chlorophyll a/b & 0.637 & -0.650 & 0.343 & 0.201 \\
Fv/Fo & -0.235 & 0.751 & 0.330 & 0.453 \\
Fv/Fm & -0.474 & 0.560 & 0.448 & 0.300 \\
Y(II) & 0.431 & 0.731 & 0.300 & -0.319 \\
qP & 0.700 & 0.257 & 0.575 & -0.077 \\
NPQ/4 & -0.380 & -0.478 & -0.020 & -0.473 \\
ETR & 0.605 & 0.757 & 0.137 & -0.003 \\
Characteristic root & 8.396 & 1.147 & 0.872 & 0.863 \\
Contribution rate & $44.642 \%$ & $25.747 \%$ & $12.479 \%$ & $7.059 \%$ \\
Cumulative contribution rate & $89.927 \%$ & & & \\
\hline & & & &
\end{tabular}

explain $44.642 \%$ of the total variation, which was closely related to the original variables of rooting rate, average root, root length, surface area, and volume $(R=0.829$ 0.939), reflecting the root morphology of the plantlets. The second principal component $\mathrm{PC} 2$ can explain $25.747 \%$ of the total variation, which was closely related to the original variables of $\mathrm{Fv} / \mathrm{Fo}, \mathrm{Y}(\mathrm{II})$, ETR ( $\mathrm{R}=0.731$ 0.757), reflecting the chlorophyll fluorescence of the plantlets. The third component PC3 can explain $12.479 \%$ of the total variation, which was negatively related to the original variable of dry weight $(R=-0.780)$, reflecting the accumulation of organic matter in the plantlets. The fourth principal component PC4 can explain $7.059 \%$ of the total variation, which was negatively related to the original variable of $\mathrm{NPQ} / 4(\mathrm{R}=-0.473)$, reflecting the heat dissipation of the excitation energy of the seedling antenna pigment system.

The quality of the C. lanceolata in vitro culture plantlets could be determined according to the comprehensive scores of PC1, PC2, PC3, and PC4. As shown in Fig. $2 \mathrm{~b}$, the comprehensive score of the photoperiod 16 $\mathrm{h}$ was significantly higher than photoperiods $8 \mathrm{~h}$ and 24 h. During photoperiod $16 \mathrm{~h}$, the light quality $\mathrm{R} / \mathrm{B} / \mathrm{P} / \mathrm{G}$ treatment had the highest comprehensive score of 1.480 , indicating that $16-\mathrm{R} / \mathrm{B} / \mathrm{P} / \mathrm{G}$ treatment was the best LED illumination condition for the growth of the C. lanceolata in vitro culture plantlets.

\section{Discussion \\ Growth}

Photoperiod can not only affect plant flowering induction and flower differentiation, but can also affect its vegetative growth and physiological and biochemical characteristics [21, 22]. Plants can sense subtle changes in light quality through photoreceptors, which in turn regulate growth and development of plants through exciting signaling pathways [23]. In the present study, we found that plantlets during photoperiod $16 \mathrm{~h}$ showed higher height, dry weight, rooting rate, average root number, root length, root surface area, and volume at most light qualities compared to photoperiods $8,24 \mathrm{~h}$. And the best plantlets were harvested with more roots and leaves. Similar results were reported by Li et al. [24], 

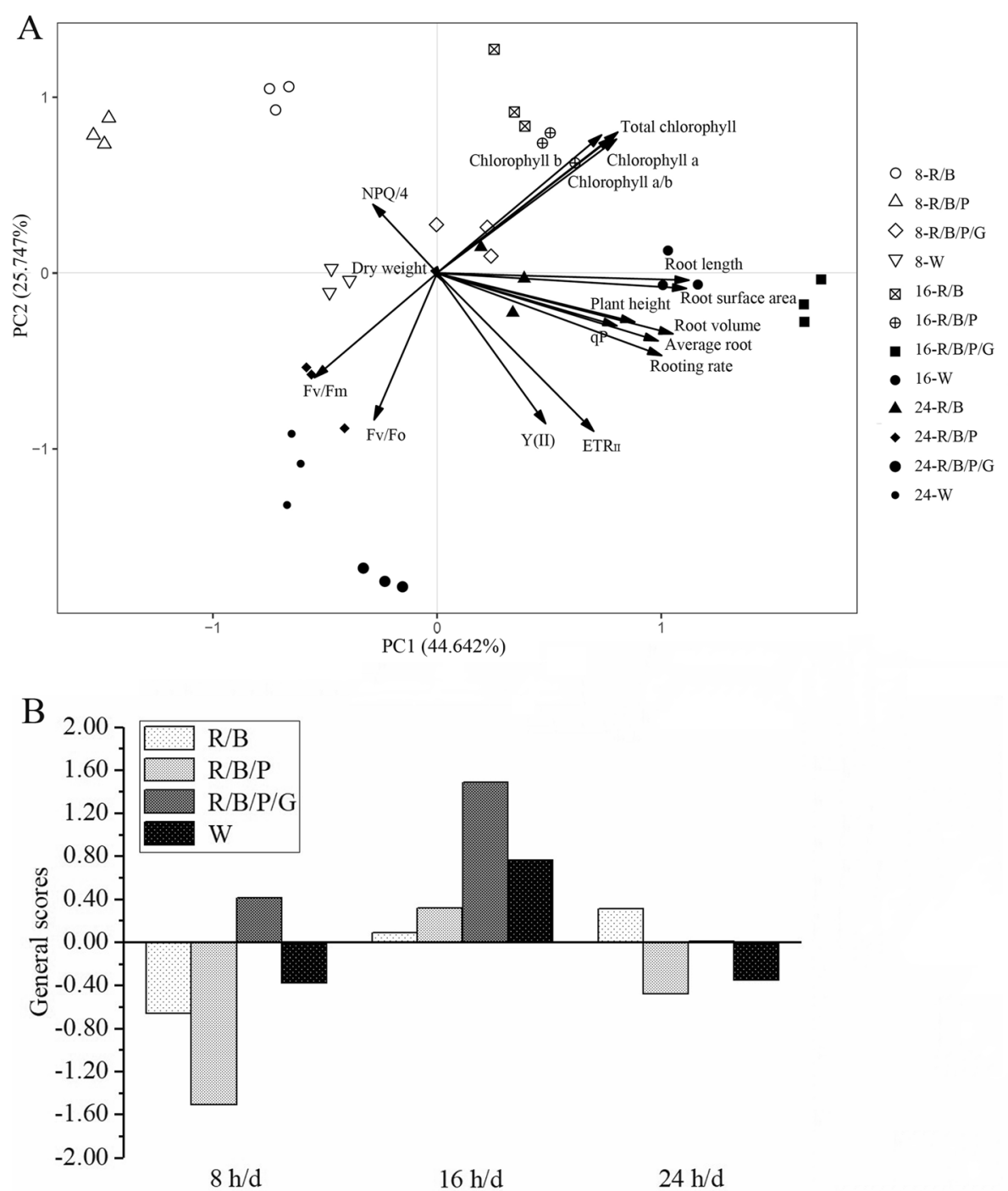

Fig. 2 Principal component analysis of 17 parameters of the C. lanceolata in vitro culture plantlets under different LED treatments. a PCA biplot. b Comprehensive score of LED photoperiod, light quality treatments

the plantlet growth and root growth of Acacia melanoxylon found to be the highest among in vitro culture under photoperiod $16 \mathrm{~h}$. Plants mainly perceive light signals through photoreceptors such as red/far red light receptors, blue/near ultraviolet photoreceptors, and ultraviolet photoreceptors, to regulate plant growth and physiological metabolism [19, 25]. Our results showed that plant height, rooting rate, root length, root surface area and root volume of $R / B / P / G$ were higher than $R / B$, $\mathrm{R} / \mathrm{B} / \mathrm{P}$ and $\mathrm{W}$ under photoperiods 8 and $16 \mathrm{~h}$, while they were lower in the $\mathrm{R} / \mathrm{B}, \mathrm{R} / \mathrm{B} / \mathrm{P}$ than $\mathrm{W}$, suggesting that the red-blue-purple-green composite light could increase growth of C. lanceolata in vitro culture plantlets. This may be due to that red and blue light are the most effectively utilized wavelengths for plants photosynthesis as absorption spectrum of photosynthetic pigments mainly focus on red light spectrum $(600-700 \mathrm{~nm})$ and blue $(400-500 \mathrm{~nm})$. Among them, red light can regulate the operation of the plant photosynthetic system and the transport of assimilates [26]; blue light is involved in stomatal opening [27]; and green light can penetrate into the plant canopy for its higher reflectivity and transmittance compared with other wavelengths lights [28]. Furthermore, phytochromes and cryptochromes are receptors not only for red and blue light, but also for purple and green light, which might explain why red light combined with blue, purple and green light $(72.7 \%$ red $+9.1 \%$ blue $+9.1 \%$ purple $+9.1 \%$ green) positively affects height and root growth of C. lanceolata plantlets cultured in vitro. 


\section{Chlorophyll}

Chlorophyll is vital for photosynthesis, which allows plants to absorb energy from light. The ratio of chlorophyll $\mathrm{a} / \mathrm{b}$ can reflect the change of photosystem, relating to the PSII: PSI content and the size of PSII light-harvesting antenna $[29,30]$. The higher level of chlorophyll a/b suggests the stronger light adaptability, the higher electron transport ability of chlorophyll and the higher activity of Calvin cycle enzyme [31]. The results of the present experiment showed that photoperiod $16 \mathrm{~h}$ treatment promoted the accumulation of chlorophyll a, chlorophyll b, total chlorophyll, and the increase of chlorophyll $\mathrm{a} / \mathrm{b}$ ratio more than other treatments examined. Our results suggested that the photoperiod $16 \mathrm{~h}$ could promote the ability of leaves of $C$. lanceolata in vitro culture plantlets to convert, capture and transfer light energy more efficiently compared to photoperiods $8,24 \mathrm{~h}$. Neither extremely short nor long photoperiods increase the chlorophyll content and the chlorophyll $\mathrm{a} / \mathrm{b}$ ratio. In addition, we also showed that chlorophyll a, chlorophyll b, total chlorophyll content, and chlorophyll $\mathrm{a} / \mathrm{b}$ ratio under $\mathrm{R} / \mathrm{B} / \mathrm{P} / \mathrm{G}$ treatment were higher than those under $\mathrm{R} / \mathrm{B} / \mathrm{P}$ treatment, indicating that the effect of red light combined with blue, purple light was not as best compared to the red-blue-purple-green composite light, because the gain effect of composite light was not a mere accumulation of monochromatic light, but the result of the interaction between spectrum and plant spectral pigment system [32, 33]. This result reflects Guo et al.' [34] finding that Paeonia suffruticosa Andr. plantlets had higher chlorophyll content under red-blue-yellowgreen-purple composite light than red-blue, red-blue-yellow, red-blue-green, and red-blue-purple composite light.

\section{Chlorophyll fluorescence}

Chlorophyll fluorescence, a nonintrusive indicator for rapid assessment of in vivo photosynthesis, is widely used in the study of the effects of different environmental conditions on plant photosynthesis. The process of light energy absorption, utilization, transfer and dissipation of PSI and PSII (mainly PSII) can be reflected by the change of chlorophyll fluorescence parameters [35]. Several studies showed that light quality has significantly effect on chlorophyll fluorescence parameters in leaves of plantlets, such as cucumber (Cucumis sativus L.) plantlets exposed to R/B 8:1 treatment significantly increased electron transport rate in PSII $\left(E R_{\mathrm{II}}\right)$ and in PSI $\left.\left(E_{T}\right)_{I}\right)$ by $176.9 \%$ and $127.0 \%$, respectively, compared with the $\mathrm{R}$ treatment [36]. Wang Y et al. [37] also found that the Fv/Fm, qP and ETR $\mathrm{EI}_{\mathrm{II}}$ of Dendrobium candidum plantlets under red and blue compound light were higher than monochrome red light. $\mathrm{Fv} / \mathrm{Fm}$ is an important indicator to measure the degree of photoinhibition and can be used to indicate the level of PSII primary light energy conversion efficiency [38]. Previous studies have shown that the $\mathrm{Fv} / \mathrm{Fm}$ of most healthy vascular plants is 0.832 [39]. If the value is greatly reduced, it means that the plant is subject to photoinhibition and the reaction center is irreversibly damaged or reversibly inactivated $[38,40]$. Although the Fv/Fm at photoperiod $16 \mathrm{~h}$ was lower than that at $8 \mathrm{~h}$ and $24 \mathrm{~h}$ in our study, the variation was small $(0.784-0.854)$, indicating that the C. lanceolata in vitro culture plantlets were not subjected to light inhibition or stress. Y(II) represents the part of energy used for photochemical reaction after absorption of PSII [41]. qP and NPQ reflect the share of light energy absorbed by PSII antenna pigments that can be used for photochemical electron transfer and the share dissipated in the form of heat, respectively $[38,42$, 43]. In this study, $\mathrm{Y}(\mathrm{II}), \mathrm{qP}, \mathrm{NPQ} / 4$ and $\mathrm{ETR}_{\mathrm{II}}$ at photoperiod $16 \mathrm{~h}$ were higher than those indicators at 8 and $24 \mathrm{~h}$ under most treatments of light combinations, suggesting that the light energy absorbed in the leaves of $C$. lanceolata in vitro culture plantlets at photoperiod $16 \mathrm{~h}$ treatments can be good used for photosynthetic electron transportation. Furthermore, the above changes might indicate that PSII function enhanced and excitation energy from reaction center increased, which was conducive to improving photosynthetic efficiency. We also found that $\mathrm{Fv} / \mathrm{Fo}, \mathrm{Y}(\mathrm{II}), \mathrm{qP}$, and $\mathrm{ETR}_{\mathrm{II}}$ under $\mathrm{R} / \mathrm{B} / \mathrm{P} / \mathrm{G}$ were higher than $\mathrm{R} / \mathrm{B}, \mathrm{R} / \mathrm{B} / \mathrm{P}$ and $\mathrm{W}$ during photoperiods 8 and $16 \mathrm{~h}$, which indicated that PSII reaction center under $\mathrm{R} / \mathrm{B} / \mathrm{P} / \mathrm{G}$ opened more than that under $\mathrm{R} /$ $\mathrm{B}, \mathrm{R} / \mathrm{B} / \mathrm{P}$ and $\mathrm{W}$, and absorbed more light energy for photosynthesis to a greater extent, and the plantlets have higher electron transfer efficiency and stronger photosynthetic capacity. It may be the reason that plantlets have higher height and greater leaves and roots under R/ $\mathrm{B} / \mathrm{P} / \mathrm{G}$ light treatment.

\section{Comprehensive analysis}

Previous studies on in vitro culture of $C$. lanceolata mainly focused on adjusting the basic growth medium. Most of the light sources were fluorescent and incandescent lamps. The rooting rate of plantlets was about 30 $70 \%$ and the average root number was about $2-4$ roots. In addition, the best culture time-period is more than 40-45 days [16]. Our results demonstrated that 16-R/B/ $\mathrm{P} / \mathrm{G}$ was best for growing $C$. lanceolata plantlets in vitro. Under this treatment, the rooting rate and the average root number were $95.50 \%$ and 4.45 , respectively, and the culture time was 30 days. The root length, root surface area and root volume could reach the highest. The results showed that we could shorten the culture time, increase the rooting rate, and harvest the best $C$. lanceolata plantlets with more leaves and roots, by using appropriate LED photoperiod and light quality. This indicated that photoperiod $16 \mathrm{~h}$ and light quality $\mathrm{R} / \mathrm{B} / \mathrm{P} /$ G $\quad(72.7 \%$ red $+9.1 \%$ blue $+9.1 \%$ purple $+9.1 \%$ green $)$ 
made the shoots and roots growth of C. lanceolata in vitro culture plantlets superior to other treatments, and the best synergistic effect on various signal receptors of light signal reception, recognition, transmission and response was produced. We also found that total chlorophyll content and ETR $\mathrm{EI}_{\mathrm{II}}$ were significant correlated with rooting rate, root length and root volume, while Fv/Fm and $\mathrm{ETR}_{\mathrm{II}}$ were significant correlated with plant height, average root number and root surface area, indicating that there were correlation between the growth of $C$. lanceolata in vitro culture plantlets and the chlorophyll and chlorophyll fluorescence of their leaves under different photoperiod and light quality. This may be because higher plants have a set of fine light receiving system and light signal transduction system, which can detect the changes of photoperiod and light quality and make adaptive response. Photoperiod and light quality may affect the growth of shoots and roots of C. lanceolate in vitro culture plantlets through two ways: one is photosynthesis through pigment system, the other is a series of physiological and biochemical reactions caused by light signal received by photoreceptor [44]. Light may be related to gene expression of carbon and nitrogen metabolism pathway [45]. The changes of light conditions (including photoperiod and light quality) may induce the regulation of photosensitive pigments on sucrose metabolizing enzymes, increase the activities of related sucrose metabolizing enzymes, and make the plantlets accumulate more photosynthates [46]. In addition, photosynthetic carbon metabolism provides energy and carbon framework for nitrogen metabolism [47], which is beneficial for the plantlets to synthesize amino acids and proteins, etc. Although light does not directly affect the growth of plant roots, it can affect root morphogenesis and growth by affecting photosynthesis and the synthesis and transport of photosynthates, but the mechanism needs to be further explored.

\section{Conclusions}

The growth, chlorophyll and chlorophyll fluorescence of C. lanceolata in vitro plantlets were found to be significantly affected by photoperiods, light qualities and their interactions. In vitro cultured plantlets subjected to photoperiod $16 \mathrm{~h}$ had longer root, higher height, rooting rate, root number, and the higher levels of chlorophyll,

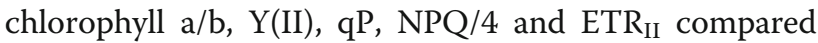
to photoperiods $8 \mathrm{~h}$ and $24 \mathrm{~h}$, but $\mathrm{Fv} / \mathrm{Fm}$ during photoperiod $16 \mathrm{~h}$ was lower than $8 \mathrm{~h}$ and $24 \mathrm{~h}$. On the other hand, plantlets exposed to $\mathrm{R} / \mathrm{B} / \mathrm{P} / \mathrm{G}$ generated more root and presented higher chlorophyll, Fv/Fo, Y(II), qP, and ETR $_{\text {II }}$ than W during photoperiods 8 and $16 \mathrm{~h}$. Total

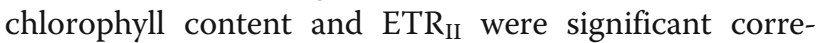
lated with rooting rate, root length and root volume, while $\mathrm{Fv} / \mathrm{Fm}$ and $\mathrm{ETR}_{\mathrm{II}}$ were significant correlated with plant height, average root number and root surface area. $16-\mathrm{R} / \mathrm{B} / \mathrm{P} / \mathrm{G}$ is best for growing $C$. lanceolata plantlets in vitro.

\section{Methods \\ Plant material}

The present experiment was conducted between March and June in 2016. The 12th generation in vitro plantlets of C. lanceolata used in this study were provided by the College of Forestry at Guangxi University in China. The plant materials were formally identified by Lecturer Rongyan Deng and deposited in the laboratory of College of Forestry at Guangxi University. The plantlets were pretreated as described by $\mathrm{Xu}$ et al. [48]. Subsequently, 540 healthy unrooted shoots with consistent growth (approximately $1.5 \pm 0.2 \mathrm{~cm}$ height) were applied to further LED experiments.

\section{Experimental design}

The "T5 2835 LED plant tube" produced by Shenzhen Weixinli Optoelectric Co., Ltd. was used as light source for cultivation. The size of the lamp is $1200 \mathrm{~mm} \times 24$ $\mathrm{mm}$, and the rated power is $16 \mathrm{~W}$. Each lamp consists of 96 sets of 2835 LED chips produced by San'an Optoelectronics. The lamp bead is evenly arranged in different color proportions, the rated voltage is AC $85-265 \mathrm{~V}$, the working current is $100 \mathrm{~mA}$ and the frequency is $50 / 60$ Hz. The peaks of emission of different LED lights are for red light at $620-630 \mathrm{~nm}, 460-470 \mathrm{~nm}$ for blue light, $410-420 \mathrm{~nm}$ for purple light, and 520-530 nm for green light. We used three photoperiods of $8 \mathrm{~h} / \mathrm{d}$ (8:00-16:00), $16 \mathrm{~h} / \mathrm{d}(8: 00-24: 00)$, and $24 \mathrm{~h} / \mathrm{d}$, and under each photoperiod set three composite lights of $88.9 \% \mathrm{red}+11.1 \%$ blue $(\mathrm{R} / \mathrm{B}), 80.0 \%$ red $+10.0 \%$ blue $+10.0 \%$ purple $(\mathrm{R} / \mathrm{B} /$ $\mathrm{P}), 72.7 \%$ red $+9.1 \%$ blue $+9.1 \%$ purple $+9.1 \%$ green $(R / B /$ $\mathrm{P} / \mathrm{G})$, and white light $(12.7 \% \mathrm{red}+3.9 \%$ blue $+83.4 \%$ green, W) was used as control. There were 12 treatments in the experiment, with 3 replications per treatment. Forty-five plantlets were used per replication, and divided into 15 bottles (3 plantlets per bottle), and cultured for $30 \mathrm{~d}$. Three replications of each treatment were placed in a separate chamber, which was separated by a dark cloth. According to the conclusion that photosynthetic photon flux density (PPFD) $30 \mu \mathrm{mol} \cdot \mathrm{m}^{-2} \cdot \mathrm{s}^{-1}$ blue light was the best for chlorophyll increased in vitro culture of C. lanceolata by Zhou et al. [18], we used two light intensities $\left(20,30 \mu \mathrm{mol} \cdot \mathrm{m}^{-2} \cdot \mathrm{s}^{-1}\right)$ with red blue $4: 1$ to screen the best light intensity for the growth of $C$. lanceolata cultured in vitro. The results showed that rooting rate, average root number and root length under $20 \mu \mathrm{mol} \cdot \mathrm{m}^{-2} \cdot \mathrm{s}^{-1}$ were higher than $30 \mu \mathrm{mol} \cdot \mathrm{m}^{-2} \cdot \mathrm{s}^{-1}$ (Unpublished data). So, $20 \mu \mathrm{mol} \cdot \mathrm{m}^{-2} \cdot \mathrm{s}^{-1}$ was used in this study. Two corresponding lamps were used in each chamber, and the distance between the light source and 
the plant was adjusted accordingly so that PPFD was constant (about $20 \pm 5 \mu \mathrm{mol} \cdot \mathrm{m}^{-2} \cdot \mathrm{s}^{-1}$ for all treatments at plant height, approximately a vertical distance of $2.5 \mathrm{~cm}$ from the culture shelf where the culture bottles were placed). PPFD was measured using a quantum sensor (LI-250A; LiCor Inc., Lincoln, NE, USA). All the cultures were incubated in a controlled environment at $25 \pm 1{ }^{\circ} \mathrm{C}$ and $60 \pm 5 \%$ relative humidity.

\section{Growth}

The total number of plantlets, rooting plantlets, and roots were counted and the rooting rate and average number of roots were calculated (see below). Ten plantlets were randomly selected for each replication for determining the root length, surface area, and volume with an Epson automatic root scanning analyzer (Seiko Epson Corporation, Nagano, Japan). Data was analyzed using a Win RHIZOC Pro 2004 b software. The calculation formula is as follows:

Rooting rate $=$ number of rooting plantlets /total number of plantlets;

Average number of roots $=$ total number of roots/total number of plantlets;

Ten plantlets were randomly selected for each replication to determine the plant height with a ruler (accuracy of $\pm 0.1 \mathrm{~cm}$ ). Ten complete plantlets per replication were placed at $105^{\circ} \mathrm{C}$ and dried in an oven at $80^{\circ} \mathrm{C}$ for $48 \mathrm{~h}$ until a constant weight was reached. The dry weight of the plants was determined using an electronic balance (accuracy $\pm 0.1 \mathrm{mg}$ ).

\section{Chlorophyll}

Chlorophyll content was estimated according to Porra et al. [49]. We randomly selected $1 \mathrm{~g}$ (fresh weight, FW) leaves from each replication were homogenized in a prechilled mortar using $20 \mathrm{~mL}$ of a 1:1 (v/v) mixture of $80 \%$ cold acetone and absolute ethanol. The homogenate was transferred to a $25 \mathrm{~mL}$ test tube, centrifuged at $4500 \mathrm{rpm}$ for $10 \mathrm{~min}$, and the supernatant collected. The absorbance was measured with Lambda 35 UV Vis spectrometer (Perkin Elmer, USA) at $663 \mathrm{~nm}\left(\mathrm{OD}_{663}\right)$ and at 645 $\mathrm{nm}\left(\mathrm{OD}_{645}\right)$ for chlorophyll a and chlorophyll $\mathrm{b}$. The chlorophyll content was determined using the following formulas:

$$
\begin{aligned}
& (\text { Chlorophyll }) \text { a }\left(m g \cdot g^{-1}\right)=\frac{\left(12.72 \times O D_{663}-2.59 \times O D_{645}\right) \times V}{1000 \times W} \\
& (\text { Chlorophyll }) \mathrm{b}\left(m g \cdot g^{-1}\right)=\frac{\left(22.88 \times O D_{645}-4.67 \times O D_{663}\right) \times V}{1000 \times W}
\end{aligned}
$$

Total chlorophyll content $\left(\mathrm{mg} \cdot \mathrm{g}^{-1}\right)=$ chlorophyll $\mathrm{a}+$ chlorophyll b
Where $\mathrm{V}$ is the total volume of acetone-ethanol extract $(\mathrm{mL})$ and $\mathrm{W}$ is FW $(\mathrm{g})$ of sample.

\section{Chlorophyll fluorescence}

Ten plantlets were randomly selected from each replication in every treatment group and placed in a dark room to adapt for $30 \mathrm{~min}$ before measuring the chlorophyll fluorescence parameters by a M-series-modulated chlorophyll fluorescence imaging system MAXI-IMAGINGPAM (Heinz Walz GmbH, Effe ltrich, Germany) at room temperature $\left(25 \pm 2{ }^{\circ} \mathrm{C}\right)$ in 9:00-12:00 a.m. The software Imaging-Win was used to control MAXI-IMAGINGPAM measuring systems to calculate the chlorophyll fluorescence parameters. The measurement was conducted using the software's standard procedures. After shading, 3 complete plantlets were randomly selected from 10 and quickly put into the adapter IMAG-MAX/GS $(10 \times 13 \mathrm{~cm})$ of MAXI-IMAGING-PAM. Ten Area of Interest (AOI) were selected evenly on the leaves of these three plantlets by the software for measuring chlorophyll fluorescence parameters. Minimum fluorescence (Fo) and maximum fluorescence (Fm) yields were measured at a weak modulated measuring beam $\left(<0.5 \mu \mathrm{mol} \cdot \mathrm{m}^{-2} \cdot \mathrm{s}^{-1}\right)$ and a saturating pulse of light $\left(2700 \mu \mathrm{mol} \cdot \mathrm{m}^{-2} \cdot \mathrm{s}^{-1}\right.$ for 0.8 s) at $1 \mathrm{~Hz}$, respectively. The fluorescence kinetics was induced by turning on the photochemical light $\left(110 \mu \mathrm{mol} \cdot \mathrm{m}^{-2} \cdot \mathrm{s}^{-1}\right)$ for $5 \mathrm{~min}$, and the maximum fluorescence under light adaptation ( $\left.\mathrm{Fm}^{\prime}\right)$ and the actual fluorescence (F) were measured by turning on the saturating pulse every $20 \mathrm{~s}$. All relevant fluorescence parameters, including photochemical efficiency of photosystem II (PSII) (Fv/Fo), maximum quantum yield of PSII (Fv/Fm), effective photochemical quantum yield of PSII (Y(II)), photochemical quenching coefficient $(\mathrm{qP})$, non-photochemical quenching coefficient $(\mathrm{NPQ} / 4)$, and relative electron transport rate of PSII $\left(\mathrm{ETR}_{\mathrm{II}}\right)$ were given automatically by the instrument. Three plantlets were measured per replication as mentioned above, and per measurement was repeated thrice. The mean of the three measurements was the value of the chlorophyll fluorescence parameters of each replication.

\section{Data analysis}

One-Way ANOVA and Duncan multiple comparisons $(P<0.05$ for significant differences) were used to analyze the differences of each experimental data (Supplementary file 1). Two-Way ANOVA was used to analyze the variance of all experimental data. Meanwhile, the relationship between growth parameters and chlorophyll fluorescence parameters was analyzed by Multiple Stepwise Regression Analysis. The above analysis was performed by SPSS software version 21.0 (IBM Inc., Chicago, IL, USA). Principal Component Analysis (PCA) was used to evaluate the all parameters and to select the 
best combination of LED photoperiod and light quality for in vitro culture plantlets of $C$. lanceolata. The histogram and biplot were plotted using Origin 2017 SR2 software (OriginLab Inc., Hampton, MA, USA) and R v3.6.2 with the package "ggplot2", respectively.

\section{Supplementary information}

Supplementary information accompanies this paper at https://doi.org/10. 1186/s12870-020-02480-7.

\section{Additional file 1.}

\section{Abbreviations}

LEDs: Light emitting diodes; R/B: Red-blue light; R/B/P: Red-blue-purple light; R/B/P/G: Red-blue-purple-green light; W: White light; Fv/Fo: Photochemical efficiency of photosystem II (PSII); Fv/Fm: Maximum quantum yield of PSII; Y (II): Effective photochemical quantum yield of PSIl; qP: Photochemical quenching coefficient; NPQ/4: Non-photochemical quenching coefficient; ETR: Relative electron transport rate in PSII; PC: Principal components; PCA: Principal Component Analysis

\section{Acknowledgements}

We thank Chaofan Chen for discussion of data analyses. We are also grateful to Yihui Zhao, Hongtao Yi, and Songya Ma for providing some help in this study.

\section{Authors' contributions}

YX and MY conceived and designed the research. YX and $Y L$ collected, analyzed the data, and prepared the manuscript. FC and SL discussed the results and revised the manuscript. All of the authors read and approved the manuscript.

\section{Funding}

The research was supported by the Guangxi specific grant for innovationdriven development Projects (AA 17204087-8). We thank the foundation of economic support. The funding organizations provided the financial support to the research projects, but were not involved in the design of the study, data collection, analysis of the data, or the writing of the manuscript.

\section{Availability of data and materials}

All data generated or analysed during this study are included in this published article and its supplementary information files.

\section{Ethics approval and consent to participate}

Not applicable.

\section{Consent for publication}

Not applicable.

\section{Competing interests}

The authors declare that the research was conducted in the absence of any commercial or financial relationships that could be construed as a potential conflict of interest.

\section{Author details}

${ }^{1}$ Guangxi Key Laboratory of Forest Ecology and Conservation, College of Forestry, Guangxi University, Nanning 530004, Guangxi, PR China. ${ }^{2}$ College of Forestry, Beijing Forestry University, Beijing 100083, PR China. ${ }^{3}$ College of Resources and Environment, Fujian Agriculture and Forestry University, Fuzhou 350002, Fujian, PR China.

Received: 7 July 2019 Accepted: 2 June 2020

Published online: 09 June 2020

\section{References}

1. Reuveni M, Evenor D. On the effect of light on shoot regeneration in petunia. Plant Cell Tiss Org. 2007;89(1):49-54.
2. Massa GD, Kim HH, Wheeler RM, Mitchell CA. Plant productivity in response to LED lighting. HortScience. 2008;43(7):1951-6.

3. Río-Álvarez I, Rodríguez-Herva JJ, Martínez PM, González-Melendi P, GarcíaCasado G, Rodríguez-Palenzuela P, López-Solanilla E. Light regulates motility, attachment and virulence in the plant pathogen Pseudomonas syringae pv tomato DC3000. Eeviron Microbiol. 2014;16(7):2072-85.

4. Kim SJ, Hahn EJ, Heo JW, Paek KY. Effects of LEDs on net photosynthetic rate, growth and leaf stomata of Chrysanthemum plantlets in vitro. Sci Hortic. 2004;101(1):143-51.

5. Gupta SD, Jatothu B. Fundamentals and applications of light-emitting diodes (LEDs) in in vitro plant growth and morphogenesis. Plant Biotechnol Rep. 2013;7:211-20.

6. Kim YW, Moon HK. Enhancement of somatic embryogenesis and plant regeneration in Japanese red pine (Pinus densiflora). Plant Biotechnol Rep. 2014;8(3):259-66.

7. Kwon AR, Cui HY, Lee H, Shin H, Kang KS, Park SY. Light quality affects shoot regeneration, cell division, and wood formation in elite clones of Populus euramericana. Acta Physiol Plant. 2015;37(3):65

8. Hung CD, Hong CH, Kim SK, Lee KH, Park JY, Nam MW, Choi DH, Lee HI. LED light for in vitro and ex vitro efficient growth of economically important highbush blueberry (Vaccinium corymbosum L.). Acta Physiol Plant. 2016;38(6):152.

9. Nhut DT, Nam NB. Light-emitting diodes (LEDs): an artificial lighting source for biological studies. The third international conference on the development of biomedical engineering in Vietnam. Berlin, Heidelberg: Springer; 2010. p. 134-9.

10. Huang W, Yang G, Li F, Zheng L, Ma J. Effects of different light qualities-LED on apple root-stock JM7 tissue culture seedling. Am J Plant Biol. 2018;3(2): $17-20$.

11. Jiang $L$, Wang $Z$, Jin G, Lu D, Li X. Responses of "Favorita" potato plantlets cultured in vitro under fluorescent and light-emitting diode (LED) light sources. Am J Potato Res. 2019: 96(4): 396-402.

12. Cho KH, Laux VY, Wallace-Springer N, Clark DG, Folta KM, Colquhoun TA Effects of light quality on vegetative cutting and in vitro propagation of Coleus (Plectranthus scutellarioides). HortScience. 2019;54(5):926-35.

13. Zhang Q, Zhou J, Li X, Liu C, Lin W, Zheng W, Chen Y, Yang Y. Nitrogen addition accelerates the nitrogen cycle in a young subtropical Cunninghamia lanceolata (Lamb.) plantation. Ann Forest Sci. 2019;76(2):31.

14. Song C, Shen W, Du L, Wen J, Lin J, Li R. Development and chemical characterization of Casparian strips in the roots of Chinese fir (Cunninghamia lanceolata). Trees. 2019;33(3):827-836.

15. Qin LF. Establishment of tissue culture technique system on Cunninghamia lanceolata superior clone. J Southern Agric. 2018;49(6):1183-8 (in Chinese).

16. Wen QL, Qin LF, Li YM, Mo XF. Effects of IAA and NAA on the rooting formation of tissue culture Chinese fir superior. Hubei Agric Sci. 2016;55(14): 3720-2 (in Chinese)

17. Ding GC, Kang JY, Lin SZ, Wu ZM, Zhou JY. Rapid two-step tissue culture propagation method of China fir based on LED (light emitting diode) light source. Fujian: CN102726299A, 2012-10-17. (in Chinese).

18. Zhou JY, Peng ZQ, Xu SS. Effect of light quality on the growth of tissue culture chlorophyll and chlorophyll fluorescence in Cunninghamia lanceolata. Chinese J Trop Crops. 2016;37(9):1759-65 (in Chinese).

19. Ouzounis T, Fretté X, Ottosen CO, Rosenqvist E. Spectral effects of LEDs on chlorophyll fluorescence and pigmentation in Phalaenopsis Vivien'and 'purple star'. Physiol Plantarum. 2015;154(2):314-27.

20. Wang Z, Tian J, Yu B, Yang L, Sun Y. LED light spectrum affects the photosynthetic performance of Houttuynia cordata seedlings. Am J Opt Photonics. 2015;3(3):38-42.

21. Hayama R, Coupland G. The molecular basis of diversity in the photoperiodic flowering responses of Arabidopsis and rice. Plant Physiol. 2004;135(2):677-84

22. Arena C, Tsonev T, Doneva D, De Micco V, Michelozzi M, Brunetti C, Centritto M, Fineschi S, Velikova V, Loreto F. The effect of light quality on growth, photosynthesis, leaf anatomy and volatile isoprenoids of a monoterpene-emitting herbaceous species (Solanum Iycopersicum L.) and an isoprene-emitting tree (Platanus orientalis L.). Environ Exp Bot. 2016;130: 122-32

23. Ward JM, Cufr CA, Denzel MA, Neff MM. The Dof transcription factor OBP3 modulates phytochrome and cryptochrome signaling in Arabidopsis. Plant Cell. 2005:17(2):475. 
24. Li S, Zhou L, Wu S, Liu L, Huang M, Lin S, Ding G. Effects of LED light on Acacia melanoxylon bud proliferation in vitro and root growth ex vitro. Open Life Sci. 2019;14(1):349-57.

25. Olle M, Viršile $A$. The effects of light-emitting diode lighting on greenhouse plant growth and quality. Agr food sci. 2013;22(2):223-34.

26. Baroli I, Price GD, Badger MR, von Caemmerer S. The contribution of photosynthesis to the red light response of stomatal conductance. Plant Physiol. 2008;146(2):737-47

27. Gruszecki WI, Luchowski R, Zubik M, Grudzinski W, Janik E, Gospodarek M, Goc J, Gryczynski Z, Gryczynski I. Blue-light-controlled photoprotection in plants at the level of the photosynthetic antenna complex LHCII. J Plant Physiol. 2010;167(1):69-73.

28. Wang Y, Folta KM. Contributions of green light to plant growth and development. Am J Bot. 2013;100:70-8.

29. Pfannschmidt T, Nilsson A, Allen JF. Photosynthetic control of chloroplast gene expression. Nature. 1999;397(6720):625.

30. Leong TY, Anderson JM. Adaptation of the thylakoid membranes of pea chloroplasts to light intensities. II. Regulation of electron transport capacities, electron carriers, coupling factor (CF 1) activity and rates of photosynthesis. Photosynth Res. 1984;5(2):117-28.

31. Evans JR. Acclimation by the thylakoid membranes to growth irradiance and the partitioning of nitrogen between soluble and thylakoid proteins. Funct Plant Biol. 1988;15(2):93-106.

32. Liu XY, Xu ZG, Chang TT, Guo SR. Growth and photosynthesis of cherry tomato seedling exposed to different low light of LED light quality. Acta Botan Boreali-Occiden Sin. 2010;30(4):725-32.

33. Tanaka M, Takamura T, Watanabe H, Endo M, Yanagi T, Okamoto K. In vitro growth of Cymbidium plantlets cultured under superbright red and blue light-emitting diodes (LEDs). J Hort Sci Biotechnol. 1998;73(1):39-44.

34. Guo F, Liu HP, Li BG, Zhang XM, Qi GH, Li YC. Effect of light quality on growth and partial physiological and biochemical characteristics of red raspberry tissue culture plantlets. North Hortic. 2016;22:15-9 (in Chinese).

35. Schreiber UBWN, Bilger W, Neubauer C. Chlorophyll fluorescence as a nonintrusive indicator for rapid assessment of in vivo photosynthesis. In: Ecophysiology of photosynthesis. Berlin, Heidelberg: Springer; 1995. p. 49-70.

36. Miao YX, Wang XZ, Gao LH, Chen OY, Qu M. Blue light is more essential than red light for maintaining the activities of photosystem || and I and photosynthetic electron transport capacity in cucumber leaves. J Integr Agr. 2016;15(1):87-100.

37. Wang Y, Tong YF, Chu HL, Chen XM, Guo HP, Yuan HW, Yan DL, Zheng BS. Effects of different light qualities on seedling growth and chlorophyll fluorescence parameters of Dendrobium officinale. Biologia. 2017;72(7):735-44.

38. Maxwell K, Johnson GN. chlorophyll fluorescence-a practical guide. J Exp Bot. 2000;51:10.

39. Björkman O, Demmig B. Photon yield of O 2 evolution and chlorophyll fluorescence characteristics at $77 \mathrm{~K}$ among vascular plants of diverse origins [J]. Planta. 1987;170(4):489-504.

40. Dai Y, Shao M, Hannaway D, Wang L, Liang J, Hu L, Lu H. Effect of Thrips tabaci on anatomical features, photosynthetic characteristics and chlorophyll fluorescence of Hypericum sampsonii leaves. Crop Protec. 2009;28:327-32

41. Genty B, Briantais JM, Baker NR. The relationship between the quantum yield of photosynthetic electron transport and quenching of chlorophyll fluorescence. Biochimica et Biophysica Acta (BBA)-General Subjects. 1989; 990(1):87-92.

42. Jin SH, Huang JQ, Li XQ, Zheng BS, Wu JS, Wang ZJ, Liu GH, Chen M. Effects of potassium supply on limitations of photosynthesis by mesophyll diffusion conductance in Carya cathayensis. Tree Physiol. 2011:31:1142-51.

43. Lindfors L, Holtta $T$, Lintunen A, Porcar-Castell A, Nikinmaa E, Juurola E. Dynamics of leaf gas exchange, chlorophyll fluorescence and stem diameter changes during freezing and thawing of scots pine seedlings. Tree Physiol. 2015;35:1314-s1324

44. Wang $Y$, Zhang $H$, Zhao B, Yuan X. Improved growth of Artemisia annua L hairy roots and artemisinin production under red light conditions. Biotechnol Lett. 2001;23(23):1971-3.

45. Li CX, Xu ZG, Dong RQ, Chang SX, Wang LZ, Khalil-Ur-Rehman M, Tao JM. An RNA-seq analysis of grape plantlets grown in vitro reveals different responses to blue, green, red LED light, and white fluorescent light. Front Plant Sci. 2017:8:78.

46. Kasperbauer MJ. Strawberry yield over red versus black plastic mulch. Crop Sci. 2000:40(1):171-4.
47. Huppe HC, Turpin DH. Integration of carbon and nitrogen metabolism in plant and algal cells. Annu Rev Plant Physiol Plant Mol Biol. 1994;45:577607.

48. Xu Y, Liang $Y$, Yang M. Effects of composite LED light on root growth and antioxidant capacity of Cunninghamia lanceolata tissue culture seedlings. Sc Rep. 2019;9(1):9766.

49. Porra RJ, Thompson WA, Kriedelman PE. Determination of accurate extraction and simultaneously equation for assaying chlorophyll $\mathrm{a}$ and $\mathrm{b}$ extracted with different solvents: verification of the concentration of chlorophyll standards by atomic absorption spectroscopy. Biochim Biophys Acta. 1989:975:384-94.

\section{Publisher's Note}

Springer Nature remains neutral with regard to jurisdictional claims in published maps and institutional affiliations.
Ready to submit your research? Choose BMC and benefit from:

- fast, convenient online submission

- thorough peer review by experienced researchers in your field

- rapid publication on acceptance

- support for research data, including large and complex data types

- gold Open Access which fosters wider collaboration and increased citations

- maximum visibility for your research: over $100 \mathrm{M}$ website views per year

At BMC, research is always in progress.

Learn more biomedcentral.com/submissions 